\title{
Role of Pictograms in Educating Diabetic Patients about Medication use and Life Style Modifications
}

\author{
Veintramuthu Sankar*, Ramya Krishna, Vuyyuru Krishna Reddy, Narmadha Muthu Mahendiran, \\ Sameer Hussain and Rama Parthasarathy
}

Department of Pharmacy Practice, PSG College of Pharmacy, Coimbatore-641004, India.

\begin{abstract}
Introduction: Diabetes mellitus is a chronic disease that occurs when the pancreas is no longer able to make insulin, or when the body cannot make good use of the insulin it produces. It can be controlled using oral hypoglycaemic agents and/or insulin and lifestyle modifications. This study examines the role of pictograms in educating the diabetic patients about proper medication use and lifestyle modifications. It is an open label, observational comparative study. Objectives: To educate diabetic patients about proper medication use and lifestyle modifications using pictograms. To identify whether comprehension of pictogram differs based on gender, age group, level of education and compliance to medications in diabetic patients and to develop a leaflet containing pictograms which convey information about lifestyle modifications and medication use in diabetic patients. Method: A prospective-observational comparative study of 6 months duration was undertaken with 100 participants for Phase-1 (Survey; $n=100$ ) to select the best understood pictograms from the 24 pictograms selected. This set was carried out for Phase-2 (one-on-one interview; $n=100$ ), which had Guessability and Translucency as its components. Guessability study was carried out in 50 diabetic patients and their response to pictograms was recorded in a 3 point Likert scale. Modifications were made to the pictograms based on the difficulties faced by the patients in understanding the pictograms. These modified pictograms were used for Translucency study and result was obtained using 5 point Likert scale. We use student t-test and Chi-Square test using SPSS 19 to analyze the data. Results: The results of this study show that pictograms are generally well understood by the diabetic patients when the intended meaning of the pictograms are explained and are accompanied with text. The statistically significant $p$ values were obtained only with levels of education in both Guessability (0.040) and Translucency (0.050). The overall Guessability (all pictograms included) was $69.6 \%$ and the overall Translucency was $90.9 \%$. Conclusion: The result from this study suggests that pictograms play a vital role in educating patients and can be used as an effective counselling aid in a low-literacy group of people.
\end{abstract}

Key words: Diabetes, Lifestyle modification, Guessability, Medication Use, Pictograms, Translucency.

\section{INTRODUCTION}

Diabetes mellitus is a chronic disorder that occurs when pancreas is no longer able to make insulin, or when the body cannot make good use of the insulin it produces. Insulin is a hormone made by the pancreas that acts like a key to let glucose from the food we eat pass from the blood stream into the cells in the body to produce energy. All carbohydrate foods are broken down into glucose in the blood. Insulin helps glucose get into the cells.

Inability to produce insulin or use it effectively leads to hyperglycaemia. Over the long-term high glucose levels are associated with damage to the body and failure of various organs and tissues. ${ }^{1}$

According to recent estimates, approximately 285 million people worldwide (6.6\%) had diabetes in 2010 and by 2030, 438 million people $(7.8 \%)$ of the adult population, is expected to have diabetes. Unlike in the west, where older populations are most affected, the burden of diabetes in Asian countries is disproportionately high in young to middle-aged adults. ${ }^{2-5}$

It is estimated that the total number of people with diabetes in 2010 to be around 50.8 million in India, rising to 87.0 million
Submitted date : 14/06/2015 Revised date : :03/08/2015 Accepted date : 08/09/2015

DOI: 10.5530/ijopp.8.3.4

Address for correspondence: Dr. Veintramuthu Sankar Department of Pharmacy Practice, PSG College of Pharmacy,

Coimbatore-641004, India. E-mail:sansunv@yahoo.co.in

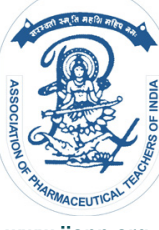

www.ijopp.org 
by 2030. According to International Diabetes Federation reports 2012, number of people living with diabetes worldwide was estimated to be 371 million and that of India is 50 million.

There are three main types of Diabetes:

Type 1 diabetes-juvenile-onset diabetes or insulin dependent diabetes

Type 2 diabetes-non-insulin dependent diabetes

Gestational diabetes-high blood glucose levels during pregnancy

According to the new WHO technical report on the prevention of diabetes and its complications, it suggests that a substantial proportion of Type 2 diabetes can be prevented through the promotion of physical activity, healthy eating and the prevention of obesity. As for people with diabetes, their quality of life can be largely preserved, and their risk of long-term complications reduced, through the provision of effective healthcare and education.

Diabetes can be effectively controlled by proper use of medication and incorporating healthy lifestyle changes. The progression of disease and complications can result from lack of knowledge about the disease due to low health literacy, improper medication use, and patient's perception towards the disease condition, unhealthy lifestyle and lack of counseling. ${ }^{6-8}$

A key step to improve the level of health communication understood by patients and their families is by providing adequate patient counseling material and tools to patients and their families. However, there are a number of barriers that need to be overcome in order to clearly convey counseling messages. Some patients do not understand how to take their medications because they are unable to read the instructions, or in the case of multiple medications, remember them all. ${ }^{9-12}$ Currently, education information on major drugs and diseases available is mainly in text format. To make matters worse, this text is written at a level too high for even the general population to understand. The problems associated with patient comprehension of medical instructions is difficult even in developed countries with higher levels of literacy, ${ }^{13}$ and are even more compounded when healthcare providers are faced with illiteracy or differences in language. ${ }^{14-16}$

These obstacles highlight the importance of accurate and effective communication between healthcare providers and patients to ensure comprehension of pharmacotherapy, thereby promoting compliance and ensuring positive patient health outcomes. The use of pictograms can help reduce the risks related to poor patient understanding of health care information and improve comprehension among patients across all literacy levels and cultures. ${ }^{17-19}$

The use of pictograms to communicate health information to people with language barriers or limited health literacy may improve patient understanding and increase the efficiency of treatment of such individuals.

Pictograms are descriptive symbols that help to convey information regarding medication and health, and can be incorporated to emphasize key counselling points. ${ }^{20-22}$

Guessability: It is the ability to make a judgment or estimate of (something) without actual knowledge or enough facts for certainty.

Translucency: Translucency refers to the relationship between the pictogram or image and its significance or referent; in other words, it is the degree to which the participant believes that the image represents what it is supposed to portray, after being told the meaning of the pictogram.

The purpose of this study is to use pictograms as an effective counselling aid in educating diabetic patients about the proper use of medication and the lifestyle modifications.

\section{METHOD}

\section{Study Design}

This prospective-observational comparative study was undertaken with 200 volunteers in a teaching hospital of PSG Medical Sciences and Research Institute, Coimbatore. This is a multispecialty 900 bedded tertiary care hospital located in the south region of Tamil Nadu. Permission for conducting the study was obtained from the Institutional Human Ethics Committee (IHEC) prior to the commencement. 100 volunteers for Phase I (survey) and 100 diabetic patients for Phase II study from various wards of the hospital were recruited.

\section{Inclusion criteria}

Patients aged over 18 years, on insulin and/or oral hypoglycemic agents (OHA), in-patients diagnosed with diabetes.

In survey, the volunteers recruited were asked to select the best understood pictogram. In Phase II, one-onone interview was carried out with pictograms to evaluate the comprehensiveness of the pictograms. Guessability was carried out in 50 diabetic patients using pictograms without text or explanation selected from Phase I. Translucency was carried out using another 50 diabetic patients with modifications made to the pictograms used in guessability study along with text and explantion. 


\section{Measures}

The data collection form included the demographics details of the patients, medical history, past and current medications, social habits, diagnosis, level of education, exercise and compliance to medications. The guessability results were assessed with a 3 point visual analog LIKERT scale as incorrect, partially correct and correct, and scored as 0, 1 and 2 respectively. The translucency results were assessed with a 5-point visual analog LIKERT scale as strongly disagree, disagree, neither, agree and strongly agree, and scored as $0,1,2,3$ and 4 respectively.

\section{Statistical analysis}

The statistical analysis was done using student t-test and chi square test by SPSS software version 19 .

\section{RESULTS}

The percentage acceptance for appeal and understanding for the pictograms were assessed in Phase I survey. (Figure $1,2)$. The pictograms with greater that $80 \%$ comprehension were selected for Phase II study and the other pictograms with lower acceptance (below 80\%) were rejected (Figure 3). The pictograms with greater that $80 \%$ comprehension were selected for Phase II study (Figure 4).

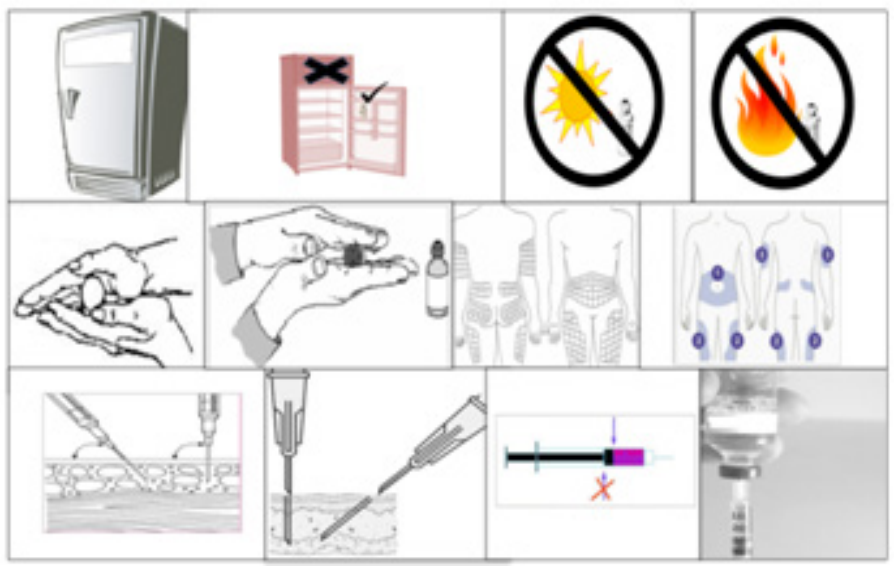

Figure 1: Pictograms in Phase 1 (Survey) Medication use

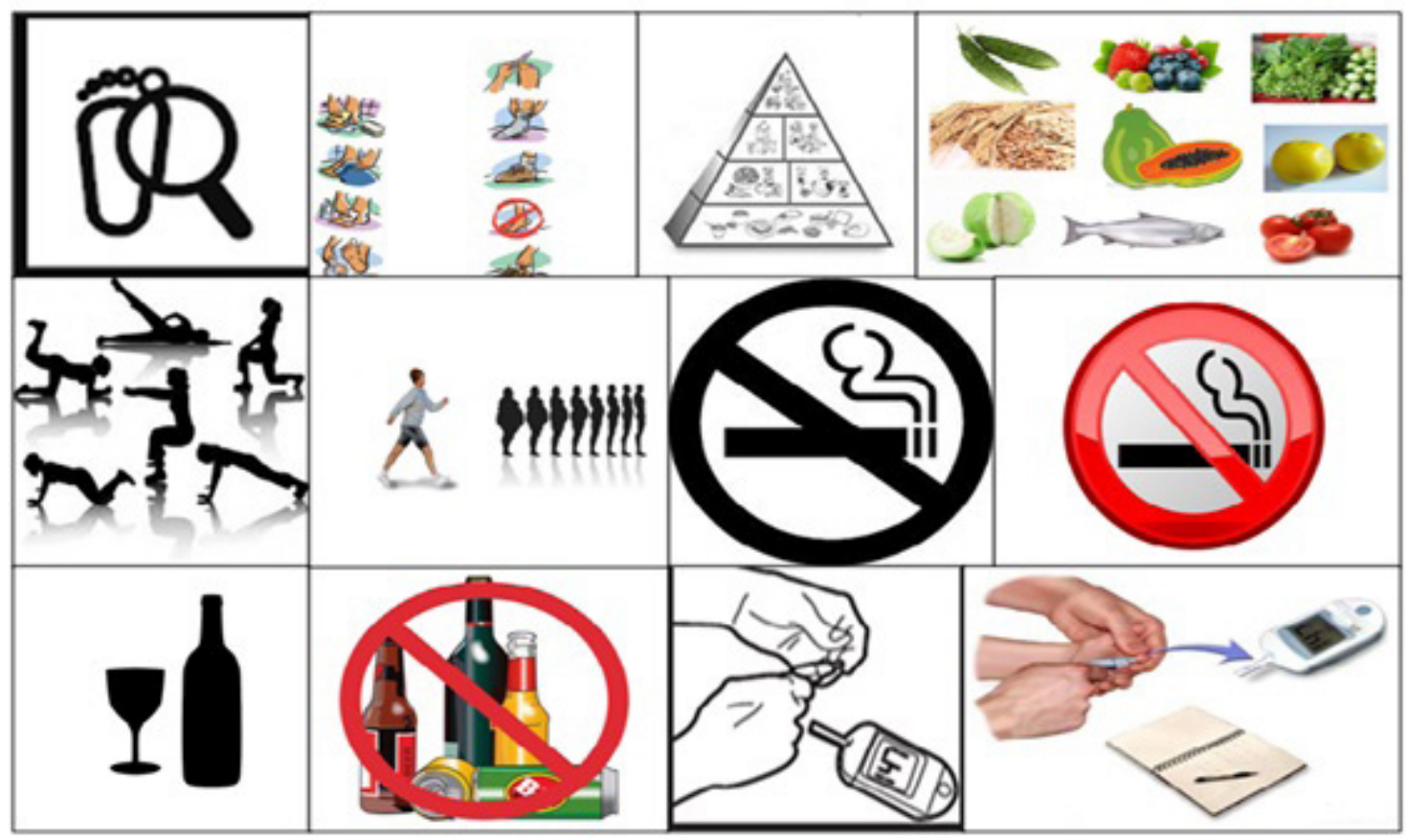

Figure 2: Life style modifications 


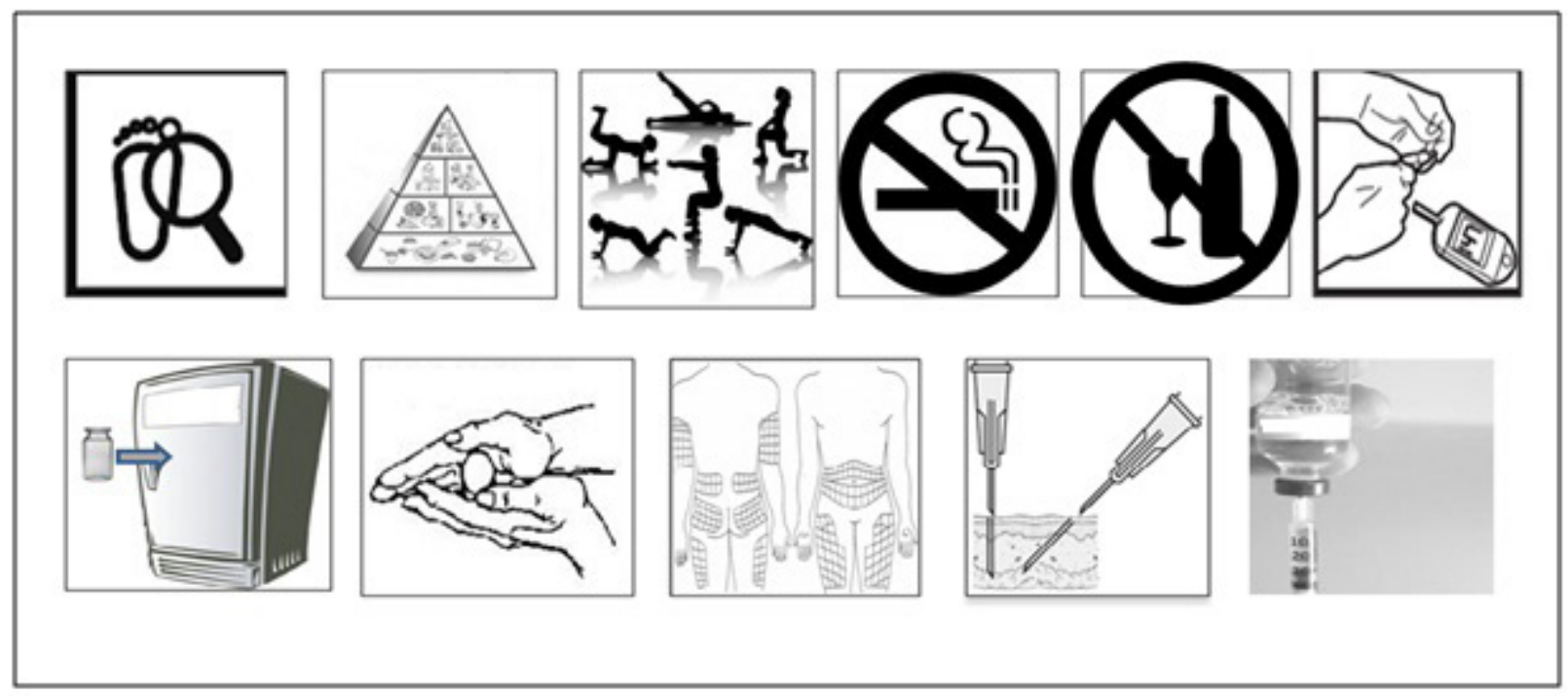

Figure 3: Rejected pictures in survey
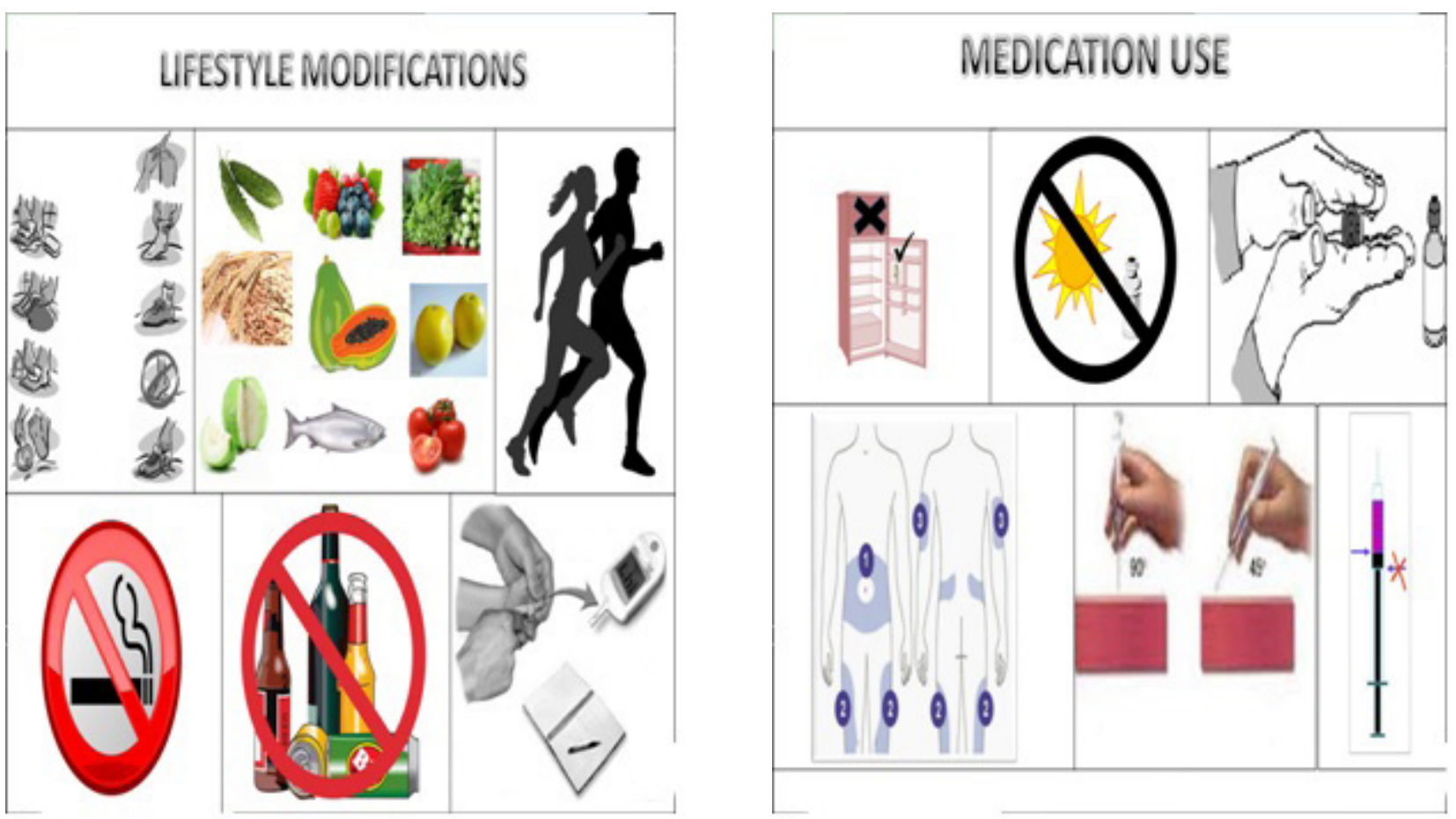

Figure 4: Pictograms selected for Phase 2 Guessability study

\section{DISCUSSION}

A total of 24 pictograms were chosen and Phase I study was carried out. Out of 24 pictograms, 12 were selected for Phase II guessability study (Figure 4). The difficulties faced by the patients in guessing the meaning of the pictograms were lack of wordings, lack of clarity, misinterpretation of pictogram and lack of colored pictograms. The modifications to the pictograms were made. The pictogram depicting foot care was changed to a colored pictogram; foods to be avoided was included; avoid smoking was replaced with a pictogram showing a man who is smoking with a "no" symbol on it; all the other pictograms were modified to a better understandable pictogram.

The pictogram developed by this study has effectively communicated information about medication use and lifestyle modifications in diabetic condition, particularly in illiterate group. Because this information is often not adequately discussed with diabetic patients as illiterate patients cannot read the prescriptions, labels, leaflets and thus, cannot remember instructions properly. It is possible that visual depiction by pictograms will stimulate greater awareness of proper medication use and lifestyle modifications. 
The proportion of men enrolled in the study was higher than women in the study population (Table 1). The number of illiterates enrolled in the phase II guessability study is more compared to higher secondary and graduate education (Table 2).

The results of this study showed that pictograms are generally well understood by the diabetic patients when the intended meaning of the pictograms were explained along with wordings.

The overall guessability (all pictograms included) was $69.6 \%$ (Table 3). The percentage increase in score was due to the inclusion of text additionally to the picto- gram. This supports the notion that pictograms are more easily interpreted by the patients when they are accompanied with text and oral explanations.

In this study, none of the pictograms were $100 \%$ correctly interpreted by patients in Phase I and Phase II initially. But we found that compared to guessability, correct interpretation of pictograms in translucency showed a marked improvement. This finding clearly indicates the need of pictograms along with text.

Moreover, the pictograms of lifestyle modifications $(59 \%)$ have guessability rates higher than that of medication use $(25.6 \%)$ (Table 4$)$. This shows that the

\begin{tabular}{|c|c|c|c|}
\hline Demographic data & Category & No of participants & Percentage (\%) \\
\hline Gender & $\begin{array}{c}\text { Male } \\
\text { Female }\end{array}$ & $\begin{array}{l}53 \\
47\end{array}$ & $\begin{array}{l}53 \\
47\end{array}$ \\
\hline Age group & $\begin{array}{l}\text { 18-35 yrs } \\
36-60 \text { yrs } \\
\text { Above } 60 \text { yrs }\end{array}$ & $\begin{array}{l}11 \\
72 \\
17\end{array}$ & $\begin{array}{l}11 \\
72 \\
17\end{array}$ \\
\hline Level of education & $\begin{array}{l}\text { Basic (up to } 8^{\text {th }} \text { grade) } \\
\text { Medium (higher secondary) } \\
\text { High (Degree/graduate) }\end{array}$ & $\begin{array}{c}7 \\
40 \\
53\end{array}$ & $\begin{array}{c}7 \\
40 \\
53\end{array}$ \\
\hline Primary language & $\begin{array}{c}\text { English } \\
\text { Tamil }\end{array}$ & $\begin{array}{l}32 \\
68\end{array}$ & $\begin{array}{l}32 \\
68\end{array}$ \\
\hline
\end{tabular}

\begin{tabular}{cccc}
\hline \multicolumn{2}{c}{ Table 2: Demographic details of Phase II (Guessability): } & \\
\hline Demographic data & Category & $\begin{array}{c}\text { No of patients } \\
(\mathbf{n = 5 0 )}\end{array}$ & Percentage (\%) \\
\hline \multirow{2}{*}{ Gender } & Male & 27 & 54 \\
& Female & 23 & 46 \\
Age group & $18-35$ yrs & 1 & 2 \\
& $36-60$ yrs & 32 & 64 \\
& Above 60 yrs & 17 & 34 \\
Level of education & Illiterate & 22 & 34 \\
& Basic (up to 8 $8^{\text {th }}$ grade) & 16 & 10 \\
Compliance to & Medium (higher secondary) & 5 & 74 \\
medications & High (Degree/graduate) & 37 & 26 \\
\hline
\end{tabular}

Table 3: Overall Guessability score percentage

\begin{tabular}{|c|c|c|c|c|c|}
\hline $\begin{array}{c}\text { Demographic } \\
\text { data }\end{array}$ & Category & $\begin{array}{c}\text { No of patients } \\
(n=50)\end{array}$ & Average score & $\begin{array}{c}\text { Score } \\
\text { Percentage (\%) }\end{array}$ & p-value \\
\hline Gender & $\begin{array}{c}\text { Male } \\
\text { Female }\end{array}$ & $\begin{array}{l}27 \\
23\end{array}$ & $\begin{array}{l}14.8 \\
11.2\end{array}$ & $\begin{array}{l}64 \\
51\end{array}$ & 0.485 \\
\hline Age group & $\begin{array}{c}18-35 \text { yrs } \\
36-60 \text { yrs } \\
\text { Above } 60 \text { yrs }\end{array}$ & $\begin{array}{c}1 \\
32 \\
17\end{array}$ & $\begin{array}{c}12 \\
12.65 \\
14.7\end{array}$ & $\begin{array}{c}54.5 \\
57.5 \\
67\end{array}$ & 0.291 \\
\hline $\begin{array}{l}\text { Level of } \\
\text { education }\end{array}$ & $\begin{array}{l}\text { Illiterate Basic } \\
\text { (up to } 8^{\text {th }} \text { grade) } \\
\text { Medium (higher } \\
\text { secondary) } \\
\text { High (Degree/ } \\
\text { graduate) }\end{array}$ & $\begin{array}{c}7 \\
22 \\
16 \\
5\end{array}$ & $\begin{array}{c}10.7 \\
11.2 \\
15 \\
15.3\end{array}$ & $\begin{array}{l}49 \\
51 \\
68 \\
69\end{array}$ & $0.040^{*}$ \\
\hline $\begin{array}{l}\text { Compliance to } \\
\text { medications }\end{array}$ & $\begin{array}{l}\text { Yes } \\
\text { No }\end{array}$ & $\begin{array}{l}37 \\
13\end{array}$ & $\begin{array}{l}14.7 \\
12.2\end{array}$ & $\begin{array}{l}66.7 \\
55.6\end{array}$ & 0.594 \\
\hline
\end{tabular}

${ }^{*}$ Correlation is significant at a level of 0.05 (2 tailed). 


\begin{tabular}{|c|c|c|c|}
\hline Pictograms & $\begin{array}{l}\text { Correct } \\
\text { (n) (\%) }\end{array}$ & $\begin{array}{l}\text { Partially correct } \\
\text { (n) (\%) }\end{array}$ & $\begin{array}{l}\text { Incorrect } \\
\text { (n) (\%) }\end{array}$ \\
\hline \multicolumn{4}{|c|}{ Lifestyle modifications } \\
\hline Foot care & $25(50 \%)$ & $16(32 \%)$ & $9(18 \%)$ \\
\hline Food habits & $27(54 \%)$ & $13(26 \%)$ & $0(0 \%)$ \\
\hline Exercise & $39(78 \%)$ & $8(16 \%)$ & $3(6 \%)$ \\
\hline Avoid smoking & $39(78 \%)$ & $3(6 \%)$ & $8(16 \%)$ \\
\hline Avoid alcohol & $36(72 \%)$ & $7(14 \%)$ & $7(14 \%)$ \\
\hline $\begin{array}{c}\text { SMBG(Self Monitoring of } \\
\text { Blood Glucose) }\end{array}$ & $11(22 \%)$ & $12(24 \%)$ & $27(54 \%)$ \\
\hline \multicolumn{4}{|c|}{ Medication use } \\
\hline Insulin storage & $17(34 \%)$ & $17(34 \%)$ & $16(32 \%)$ \\
\hline Rolling Insulin & $12(24 \%)$ & $20(40 \%)$ & $18(36 \%)$ \\
\hline Insulin injection sites & $16(36 \%)$ & $9(18 \%)$ & $25(50 \%)$ \\
\hline Angles of Injection & $4(8 \%)$ & $21(42 \%)$ & $25(50 \%)$ \\
\hline $\begin{array}{l}\text { Direction of intake of } \\
\text { medicines }\end{array}$ & $13(26 \%)$ & $18(36 \%)$ & $19(38 \%)$ \\
\hline
\end{tabular}

\section{LIFESTYLE MODIFICATIONS IN DIABETIC PATIENTS சர்க்கரை நோய் - வாழ்கை முறை மாற்றங்கள்}

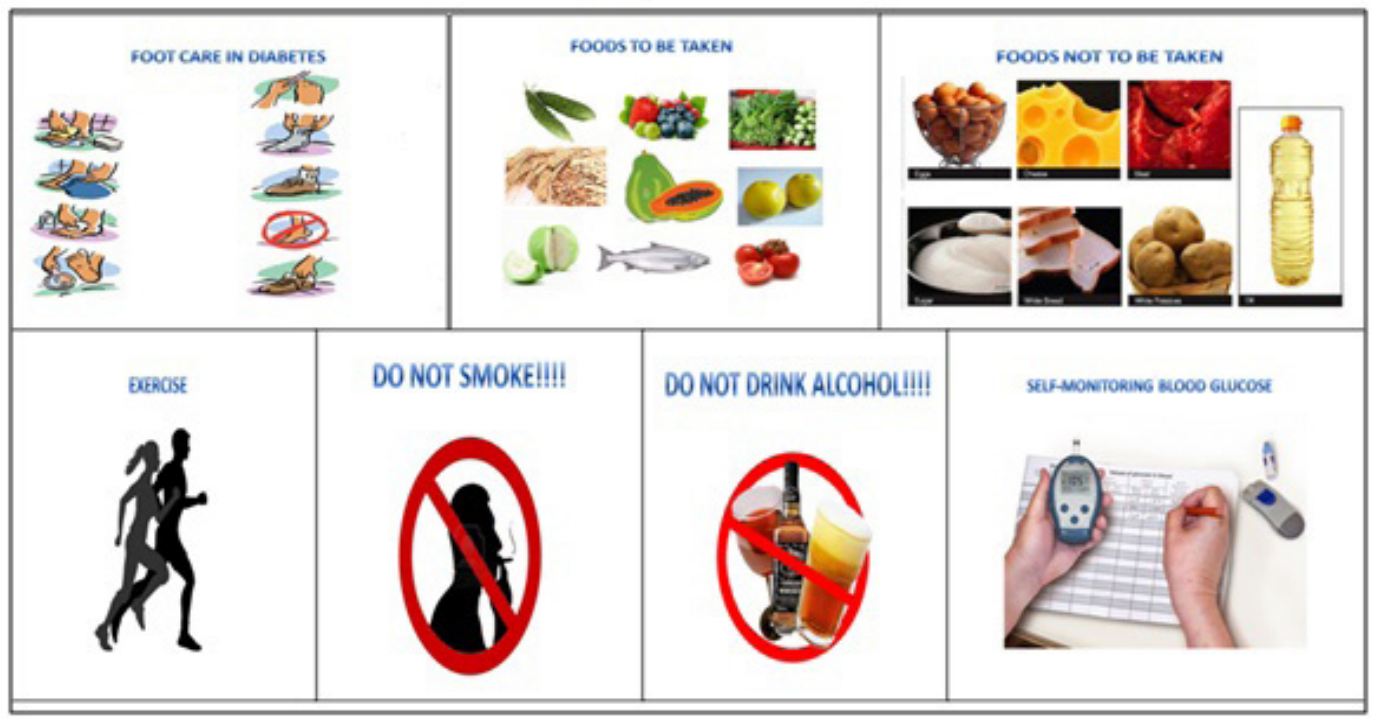

Figure 5: Pictograms selected for Phase 2 Translucency study

people are aware of the lifestyle modifications and are hence well guessed. As shown by studies ${ }^{23}$ simple pictograms like reduction in weight $(88.2 \%)$, vomiting $(88.2 \%)$, headache $(94.1 \%)$ were easy to understand compared to complex anatomical pictograms like conjunctivitis $(35.2 \%)$.

The percentage guessability for 3 pictograms namely, self monitoring blood glucose $(22 \%)$, rolling of insulin $(24 \%)$ and angle of injection (8\%) was low (Table 4). This shows that the patients are unaware of this information. When the labeled pictograms (Figure 5) are shown the patients (Table 5), they could guess the meaning of the pictograms better, for self monitoring blood glucose (44\%), rolling of insulin (52\%) and angle of injection (30\%) (Table 6). This can be supported by the study ${ }^{24}$ where the average recall assessment score was greater in the text with symbol group $(\mathrm{M}=6.65)$ as compared to symbol only group $(\mathrm{M}=6.36)$.

Furthermore, this validates the FIP-WHO statement on labeling, which recommends including written explanation with pictograms for their use in medical settings. One concern is that, there is a significant difference $(p$ value is 0.040 ) in pictogram comprehension between participants with adequate literacy and those with inad- 
Table 5: Demographic details of Phase II (Translucency)

\begin{tabular}{cccc}
\hline Demographic data & Category & No of patients $(\mathbf{n}=\mathbf{5 0})$ & Percentage (\%) \\
\hline \multirow{2}{*}{ Gender } & Male & 30 & 60 \\
& Female & 20 & 40 \\
Age group & $18-35$ yrs & 3 & 6 \\
& $36-60$ yrs & 23 & 46 \\
& Above 60 yrs & 24 & 88 \\
Level of education & Illiterate Basic (up to 8th & 4 & 38 \\
& grade) & 19 & 42 \\
Compliance to & Medium (higher secondary) & 21 & 12 \\
medications & Hegree/graduate) & 6 & 72 \\
Primary language & Yes & 36 & 28 \\
& No & 14 & 12 \\
\hline
\end{tabular}

\section{Table 6: Overall Translucency}

\begin{tabular}{|c|c|c|c|c|c|}
\hline Pictograms & $\begin{array}{l}\text { Strongly agree } \\
\text { (n) (\%) }\end{array}$ & $\begin{array}{l}\text { Agree } \\
\text { (n) }(\%)\end{array}$ & $\begin{array}{l}\text { Neither } \\
\text { (n) (\%) }\end{array}$ & $\begin{array}{c}\text { Disagree } \\
\text { (n) (\%) }\end{array}$ & $\begin{array}{c}\text { Strongly } \\
\text { Disagree } \\
\text { (n) }(\%)\end{array}$ \\
\hline \multicolumn{6}{|c|}{ Lifestyle modifications } \\
\hline Foot care & $30(60 \%)$ & $16(26 \%)$ & $4(8 \%)$ & $0(0 \%)$ & $0(0 \%)$ \\
\hline Food habits & $27(54 \%)$ & $21(42 \%)$ & $2(4 \%)$ & $0(0 \%)$ & $0(0 \%)$ \\
\hline Exercise & $42(84 \%)$ & $7(14 \%)$ & $1(2 \%)$ & $0(0 \%)$ & $0(0 \%)$ \\
\hline Avoid smoking & $42(84 \%)$ & $8(16 \%)$ & $0(0 \%)$ & $0(0 \%)$ & $0(0 \%)$ \\
\hline Avoid alcohol & $44(88 \%)$ & $6(12 \%)$ & $0(0 \%)$ & $0(0 \%)$ & $0(0 \%)$ \\
\hline $\begin{array}{l}\text { SMBG (Self } \\
\text { Monitoring of } \\
\text { Blood Glucose) }\end{array}$ & $22(44 \%)$ & $20(40 \%)$ & $7(14 \%)$ & $1(2 \%)$ & $0(0 \%)$ \\
\hline \multicolumn{6}{|c|}{ Medication use } \\
\hline Insulin storage & $27(54 \%)$ & $19(38 \%)$ & $4(8 \%)$ & $0(0 \%)$ & $0(0 \%)$ \\
\hline Rolling Insulin & $26(52 \%)$ & $19(38 \%)$ & $5(10 \%)$ & $0(0 \%)$ & $0(0 \%)$ \\
\hline $\begin{array}{l}\text { Insulin injection } \\
\text { sites }\end{array}$ & $35(70 \%)$ & $11(22 \%)$ & $4(8 \%)$ & $0(0 \%)$ & $0(0 \%)$ \\
\hline $\begin{array}{l}\text { Angles of } \\
\text { Injection }\end{array}$ & $15(30 \%)$ & $24(48 \%)$ & $11(22 \%)$ & $0(0 \%)$ & $0(0 \%)$ \\
\hline $\begin{array}{l}\text { Direction } \\
\text { of intake of } \\
\text { medicines }\end{array}$ & $21(42 \%)$ & $18(36 \%)$ & $11(22 \%)$ & $0(0 \%)$ & $0(0 \%)$ \\
\hline
\end{tabular}

equate literacy (Table 4). Even though we used a small sample, we demonstrated a significant difference. This indicates a strong relationship between literacy and pictogram comprehension. Although people with adequate literacy understand pictograms better than people with inadequate health literacy, pictograms have been shown to enhance comprehension of information even in low literacy population.

In Phase 2 study, both guessability and translucency, male have scored higher than female. But from statistical analysis, there was no significant difference obtained when the scores are correlated to gender ( $p$ value is 0.311 ).

In guessability study, patients above the age of $60 \mathrm{yrs}$ were able to guess the picture better $(67 \%)$ as compared to the other age group (18-35 yrs-54.5\%; 36-60 yrs$57.5 \%$ ) (Table 4). This can be due to the fact that elderly patients are on long term drug therapy and have better understanding about their disease condition and drugs as compared to the other categories.

Whereas in translucency, the younger population (18-35 yrs) could understand better (91\%) as compared to 36-60 yrs $(89.2 \%)$ and above $60 \mathrm{yrs}(86.1 \%)$ (Table 7$)$. This can be due to the difficulties faced by the elderly people like low level of education, other co-morbidities etc.

In both guessability and translucency study, the highly educated patients scored more $(69 \%$ and $92.8 \%$ respectively) and the illiterate patients scored the least (49\% and $69.3 \%$ respectively) (Table 4,7 ). There was statistically significant difference when levels of educa- 


\begin{tabular}{|c|c|c|c|c|c|}
\hline $\begin{array}{c}\text { Demographic } \\
\text { data }\end{array}$ & Category & $\begin{array}{l}\text { No of patients } \\
(n=50)\end{array}$ & Average score & $\begin{array}{c}\text { Score } \\
\text { Percentage (\%) }\end{array}$ & p-value \\
\hline Gender & $\begin{array}{l}\text { Male } \\
\text { Female }\end{array}$ & $\begin{array}{l}30 \\
20\end{array}$ & $\begin{array}{c}39.23 \\
37.8\end{array}$ & $\begin{array}{l}89.1 \\
85.9\end{array}$ & 0.757 \\
\hline Age group & $\begin{array}{c}18-35 \text { yrs } \\
36-60 \text { yrs } \\
\text { Above } 60 \text { yrs }\end{array}$ & $\begin{array}{c}3 \\
23 \\
24\end{array}$ & $\begin{array}{c}40 \\
39.2 \\
37.9\end{array}$ & $\begin{array}{c}91 \\
89.2 \\
86.1\end{array}$ & 0.770 \\
\hline $\begin{array}{l}\text { Level of } \\
\text { education }\end{array}$ & $\begin{array}{l}\text { Illiterate Basic } \\
\text { (up to } 8^{\text {th }} \text { grade) } \\
\text { Medium (higher } \\
\text { secondary) } \\
\text { High (Degree/ } \\
\text { graduate) }\end{array}$ & $\begin{array}{c}4 \\
19 \\
21 \\
6\end{array}$ & $\begin{array}{c}30.5 \\
39 \\
39.2 \\
40.8\end{array}$ & $\begin{array}{l}69.3 \\
88.6 \\
89.2 \\
92.8\end{array}$ & $0.050^{*}$ \\
\hline Compliance & $\begin{array}{l}\text { Yes } \\
\text { No }\end{array}$ & $\begin{array}{l}36 \\
14\end{array}$ & $\begin{array}{c}31.9 \\
37.28\end{array}$ & $\begin{array}{l}89 \\
85\end{array}$ & 0.370 \\
\hline $\begin{array}{l}\text { Primary } \\
\text { language }\end{array}$ & $\begin{array}{c}\text { English } \\
\text { Tamil }\end{array}$ & $\begin{array}{c}6 \\
44\end{array}$ & $\begin{array}{l}41.1 \\
36.2\end{array}$ & $\begin{array}{l}92.8 \\
82.3\end{array}$ & 0.915 \\
\hline
\end{tabular}

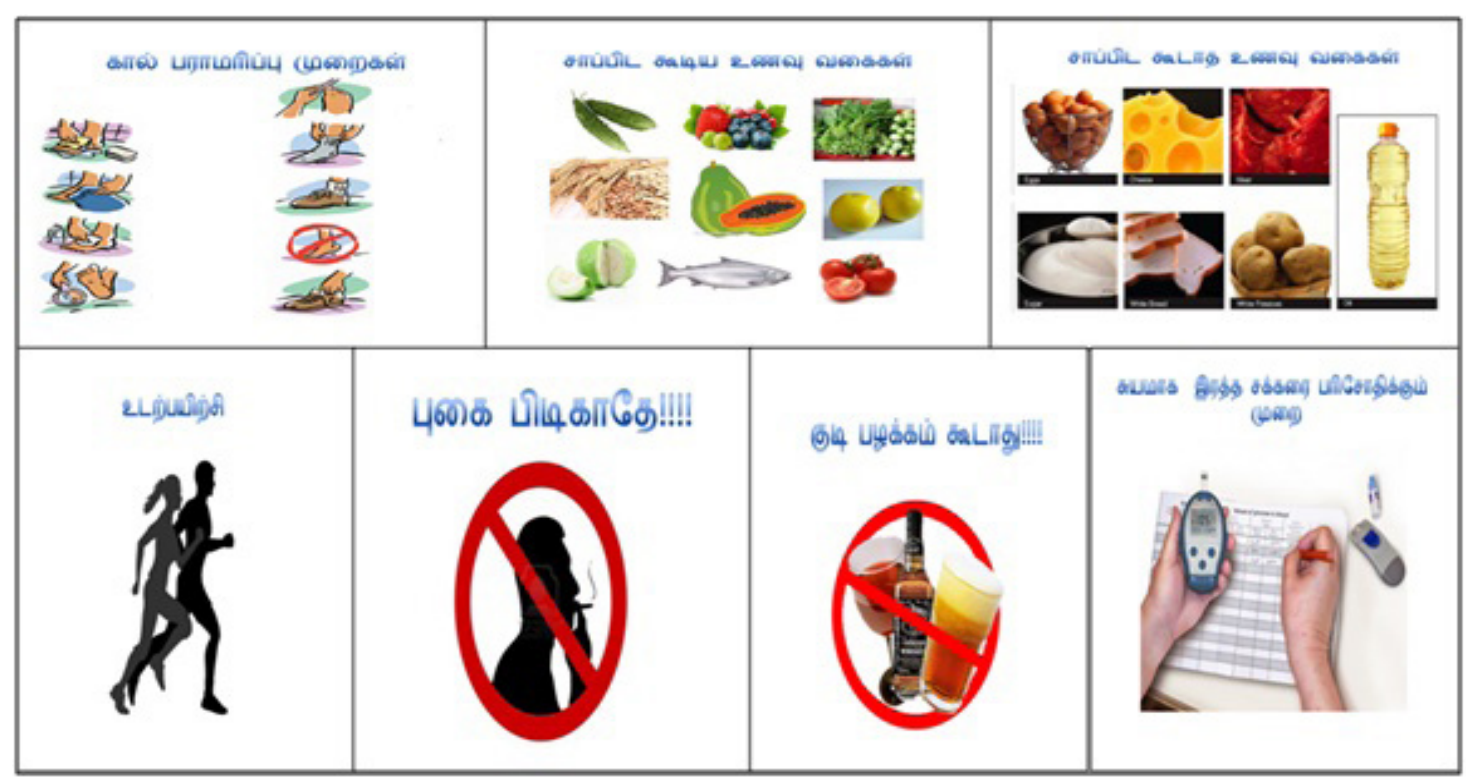

\section{MEDICATION USE IN DIABETIC PATIENTS சர்க்கரை நோய் மருந்துகள்உபயோகிக்கும் முறை}

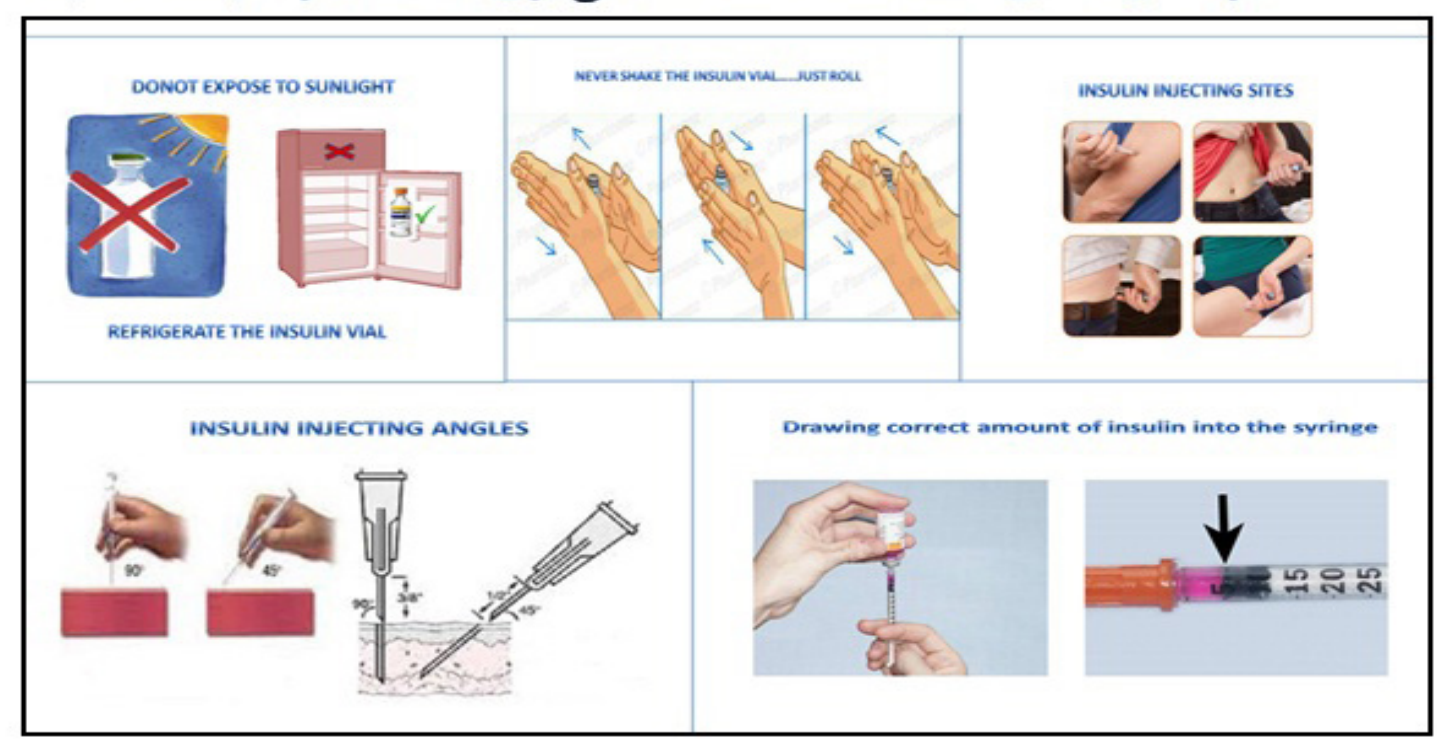



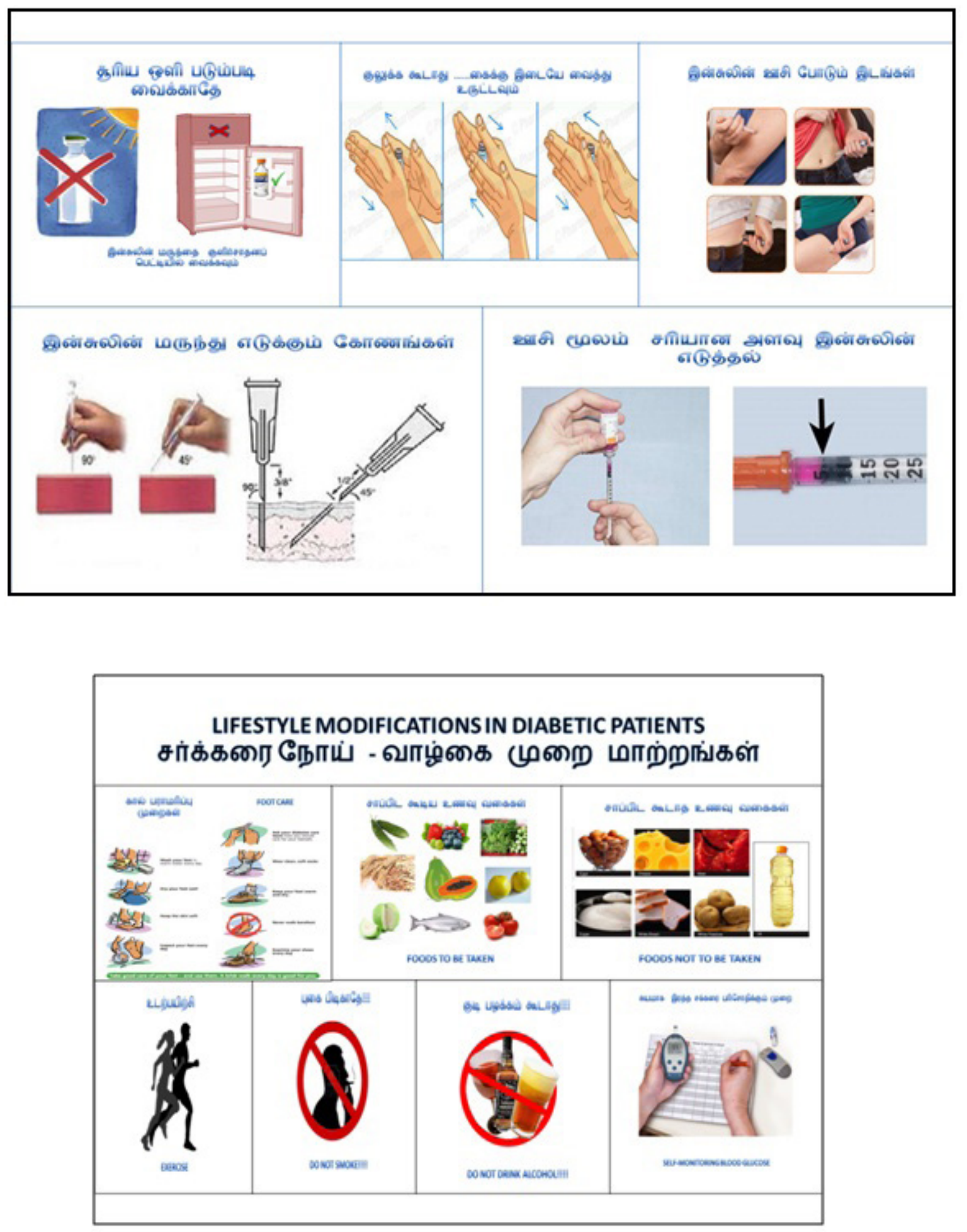

Figure 6: Leaflet developed

tion were compared to the scores of guessability and translucency ( $\mathrm{p}$-values are 0.04 and 0.05 respectively). The study ${ }^{25}$ found that there was no bivariant relation between literacy and adherence $(\mathrm{p}=0.88)$, whereas Kalichman et al mentioned that lower literacy was associated with greater odds of poor adherence. ${ }^{26-27}$

Similarly, patients with better compliance have better knowledge about the drugs and lifestyle modifica- tions. The patients who have compliance to medication obtained a score percentage of $66.7 \%$ for guessability and $89 \%$ for translucency and patients without compliance obtained $55.6 \%$ and $85 \%$ for guessability and translucency respectively. (Table 4, 7).

In translucency, patients who selected English as the primary language obtained a score percentage of $92.8 \%$ and those who selected Tamil obtained a score percent- 


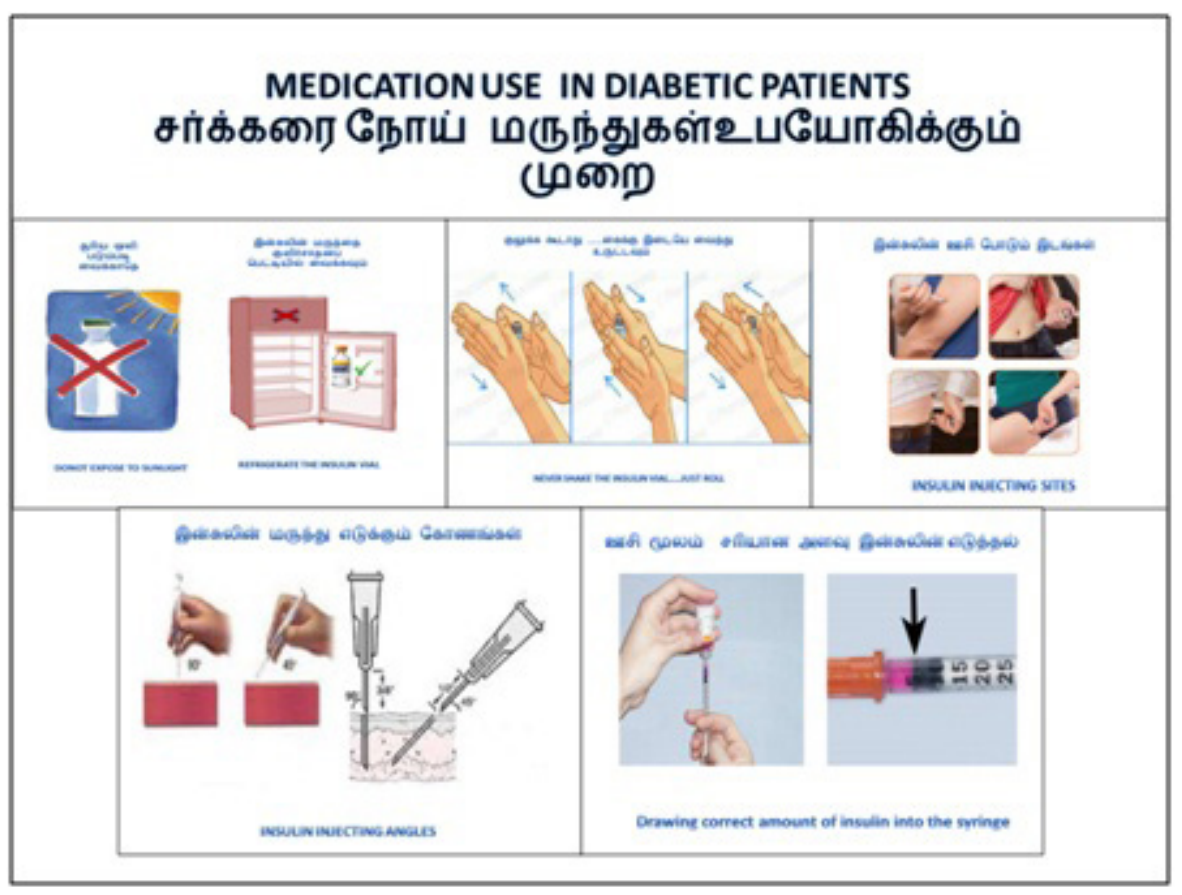

age of $82.3 \%$. But no statistical significant difference was observed. The overall translucency was $90.9 \%$.

\section{CONCLUSION}

This study concludes that pictograms play a vital role in educating patients and can be used as an effective counseling aid in a low-literacy group of people. Moreover, comprehension and recall of information can be improved by using pictograms in addition to written format of information.

In a total of 24 pictograms, 12 pictograms were selected for the Phase 2 study. Using these 12 pictograms we have educated the diabetic patients under study about the lifestyle modifications and medication use effectively.

Furthermore, we have developed a (Figure 6) that contains the pictograms from translucency, which can be

\section{REFERENCES}

1. Introduction, International Diabetes Federation available at http://www.idf.org/ about-diabetes

2. Ajay VS. Prevalence and determinants of diabetes mellitus in the Indian industrial population. Diabetic medicine 2008 Oct; 25(10): 1187-94.

3. Huizinga MM. Addressing the diabetes pandemic: A comprehensive approach. Indian J Med Res. 2006; 124(5): 481-4.

4. Ramachandran A. High prevalence of diabetes in an urban population in south India. BMJ. 1988; 297(6648): 587-90.

5. Ramachandran A. Current Status of Diabetes in India and Need for Novel Therapeutic Agents. Supplement to Jape 2010 June; 58: 7-9.

6. Christopher Sorfleet. Design, Development and evaluation of pictographic instructions for medications used during humanitarian missions. Cpj/rpc. 2009 March/April; 142(2): 83-8.

7. Andersson CM. A stage model for assessing a community-based diabetes prevention program in Sweden. Health promotion international 2003 Dec; 17(4): 317-27. used as a counseling aid in the Drug Information Centre (DIC) of PSG College of Pharmacy located at PSG Hospital.

\section{ACKNOWLEDGEMENTS}

The authors sincerely thank Dr. M. Ramanathan, Principal, PSG College of Pharmacy for his guidance and support. We extend our thanks to Endocrinology department, PSG Hospitals for their kind help during the study. We also thank Dr Regis Vaillancourt, Director, Children's Hospital of Eastern Ontario, Ottawa, Canada for providing literatures and guidance during the study period. Our thanks to all the patients and staff of PSG Institute of Medical Sciences and Research for all their help and cooperation during the study period.
8. Centers for Disease Control and Prevention. National Diabetes Fact Sheet, 2011. Atlanta, GA: Centers for Disease Control and Prevention, US Department of Health and Human Services; 2011. http://www.cdc.gov/diabetes/pubs/pdf/ ndfs_2011.Pdf. Accessed April 16, 2012.

9. The Diabetes Control and Complications Trial Research Group. The effect of intensive treatment of diabetes on the development and progression of long-term complications in insulin-dependent diabetes mellitus. New England Journal of Medicine 1993; 329(14): 977-86.

10. Centers for Disease Control and Prevention. Natural Experiments for Translation in Diabetes (NEXT-D) Study. Diabetes Public Health Resource Web site. http://www.cdc. gov/diabetes/projects/next-d.htm. Access April 16, 2012.

11. Davis TC. Literacy and misunderstanding prescription drug labels. Ann Intern Med. 2006; 145(12): 887-94.

12. Kripalani S. Development of an illustrated medication schedule as a lowliteracy patient education tool. Patient Education and Counselling 2007; 66(3): 368-77. 
13. Cho YI, Lee. Effects of health literacy on health status and health service utilization amongst the elderly. Soc Sci Med. 2008; 66(Issue Missing?): 1809-16.

14. DiMatteo MR. Variations in Patients adherence to medical recommendations: a quantitative review of 50 years of research. Med Care 2004; 42(3): 200-9.

15. Hoc AD. Committee on Health Literacy for the American Council on Scientific Affairs, American Medical Association. Health literacy: Report of the council on scientific affairs. JAMA. 1999; 281(6): 552-7.

16. International Standards Organization, Procedures for the development and testing of public Information symbols ISO9186: Geneva, Switzerland; 1989.

17. Dowse R. Medicine labels incorporating pictograms: Do they influence understanding and adherence? Patient Education and Counselling 2005; 58(1): 63-70.

18. Kassam R, Vaillanourt R, Collins JB. Pictographic instructions for medications: Do different cultures interpret them accurately? International Journal of Pharmacy Practice 2004; 12(4): 199-209.

19. Katri Hämeen-Anttila. Do pictograms improve children's understanding of medicine leaflet information? Patient Education and Counseling 2004; 55(3): 371-8. www.elsevier.com/locate/pateducou

20. Sachdev Yadav. Pharmaceutical Pictogram in Rationale Use of Drug and Development of Pharmaceutical Care Services: A Mini Review. International Journal of Research in Pharmaceutical and Biomedical Sciences 2012; 3(1): 215-21.
21. Sorfleet C, Vaillancourt R. Design, development and evaluation of pictographic instructions for medications used during humanitarian missions. Canada Pharmaceutical Journal 2009; 142(2): 83-8.

22. Bachrach R. Using pictographs to enhance recall of spoken medical instructions. Patient Education and Counselling 1998; 35(2): 83-8.

23. Rajesh Radhakrishnan. Design and evaluation of pictograms for communicating information about adverse drug reactions to antiretroviral therapy in Indian human immuno deficiency virus positive patients. Journal of Pharmaceutical and Biomedical Sciences 2012; 16(16): 10.

24. Sean R, King. The Influence of Symbols on the Short-Term Recall of PharmacyGenerated Prescription Medication Information in a Low Health Literate Sample. Journal of Health Communication 2012; 17(S3): 280-93.

25. Golin CE, Liu H, Hays RD. A prospective study of predictors of adherence to combination antiretroviral medication. Journal of General Internal Medicine 2002; 17(10): 756-65.

26. Kalichman SC, Ramachandran B, Catz S. Adherence to combination antiretroviral therapies in HIV patients of low health literacy. Journal of General Internal Medicine 1999; 14(5): 267-73.

27. Houts PS. Using pictographs to enhance recall of spoken medical instructions. Patient Education and Counselling 1998; 35(2): 83-8. 